\title{
Seagrass in Malaysia: issues and challenges ahead
}

\begin{abstract}
Seagrasses are submerged monocotyledonous angiosperms living in marine and estuarine habitats. They are plants differentiated into distinct segments: rhizomes, roots, and leaves. Seagrasses vary in morphology and size, ranging from the tropical eelgrass Enhalus acoroides with strap-like leaves that reach $1 \mathrm{~m}$ or more in height to shorter ovate leaved spoongrass Halophila ovalis that grows to only a few centimeters tall. Seagrasses produce flowers and seeds, disperse seeds and propagate vegetatively to maintain meadows. There are 16 species of seagrasses in Malaysia comprising Enhalus acoroides, Halophila beccarii, Halophila decipiens, Halophila ovalis, Halophila major, Halophila minor, Halophila spinulosa, Halophila sp., Halodule pinifolia, Halodule uninervis, Cymodocea rotundata, Cymodocea serrulata, Thalassia hemprichii, Syringodium isoetifolium, Thalassodendron ciliatum, and Ruppia maritima. Healthy seagrasses may grow dense and form an extensive beds or meadows. Their characteristics and interactive community within and from outside account for the high diversity and enable survival of diverse invertebrates (shrimps, sea cucumbers, starfishes, bivalves, gastropods), vertebrates (dugongs, green sea turtles, fishes) and macroalgae. Seagrasses provide conditions for the growth and abundance of invertebrates and fish that many local coastal communities collect and catch for their livelihood. Seagrass ecosystems are sources of food and continually facing threats by natural events and, human activities, e.g., coastal development causing their fast degradation and possible habitat loss.
\end{abstract}

Keyword: Seagrass; Diversity; Significance; Malaysia; Threats 